\title{
A subset of mobilized human hematopoietic stem cells express germ layer lineage genes which can be modulated by culture conditions
}

Tapas Makar1,2,3, Vamshi K. Nimmagadda 1,3, Poornachander R. Guda 1,3, Brian Hampton4, Weiliang Huang,6, Maureen A. Kane ${ }^{5,6}$, Paul S. Fishman ${ }^{1,3}$, Bernard Pessac ${ }^{7,8^{\wedge}}$, Christopher T. Bever Jr. ${ }^{1,2,3^{*}}$ (D) and David Trisler ${ }^{1,2,3}$

\begin{abstract}
Background: Adult bone marrow contains stem cells that replenish the myeloid and lymphoid lineages. A subset of human and mouse CD34 $4^{+}$bone marrow stem cells can be propagated in culture to autonomously express embryonic stem cell genes and embryonic germ layer lineage genes. The current study was undertaken to determine whether these CD34 $4^{+}$stem cells could be obtained from human blood, whether gene expression could be modulated by culture conditions and whether the cells produce insulin.

Methods: Human peripheral blood buffy coat cells and mobilized CD34 ${ }^{+}$cells from human blood and from blood from C57BI/6 J mice were cultured in hybridoma medium or neural stem cell induction medium supplemented with interleukin (IL)-3, IL-6, and stem cell factor (SCF). Changes in mRNA and protein expression were assessed by Western blot analysis and by immunohistochemistry. Mass spectrometry was used to assess insulin production.

Results: We were able to culture $\mathrm{CD}_{34}{ }^{+}$cells expressing embryonic stem cell and embryonic germ layer lineage genes from adult human peripheral blood after standard mobilization procedures and from mouse peripheral blood. Gene expression could be modulated by culture conditions, and the cells produced insulin in culture.
\end{abstract}

Conclusion: These results suggest a practical method for obtaining large numbers of CD34 ${ }^{+}$cells from humans to allow studies on their potential to differentiate into other cell types.

Keywords: CD34 stem cells, Human bone marrow stem cell, ESC genes, Lineage genes, Pancreas, Insulin

\section{Background}

Adult bone marrow contains stem cells that replenish the myeloid and lymphoid lineages throughout life $[1,2]$. In addition to the expected hematopoietic stem cell genes CD34, cKit, and CD45 [3], a subset of these adult human and mouse $\mathrm{CD} 34^{+}$bone marrow stem cells express the embryonic stem cell genes Oct-4, Sox-2, LIN-28 [4], and embryonic germ layer lineage genes such as ectodermal neuronal (neurofilament, tubulin)

\footnotetext{
* Correspondence: Christopher.bever@va.gov

'Deceased

${ }^{1}$ Department of Neurology, University of Maryland School of Medicine, Baltimore, MD 21201, USA

${ }^{2}$ Multiple Sclerosis Center of Excellence, East VA Maryland Health Care

System, Baltimore, MD 21201, USA

Full list of author information is available at the end of the article
}

and oligodendroglial (NG-2, MOG, PLP, MBP (human)), mesodermal cardiac (MEF, troponin C, MLC-2), and endodermal pancreatic (Pdx-1, Ptf1 $\alpha$, Ngn-3, FoxA2, Sox17, CXCR4, Hnf1B, Hnf4A, Hnf6, Nkx2.2, Pax-6, GLUT2, glucokinase, proinsulin and insulin (human)) and intestinal (villin) genes [5]. A cell culture method was developed to propagate a pure population of this subset of $\mathrm{CD}^{+} 4^{+}$stem cells [6]. The gene expression profile suggested that this subset of $\mathrm{CD}^{+} 4^{+}$stem cells might have characteristics of embryonic stem cells and might be capable of developing into cell types other than myeloid and lymphoid cells. To test this possibility, adult mouse $\mathrm{CD}^{+} 4^{+}$bone marrow stem cells were expanded in culture, labeled, and inserted into mouse blastocysts to determine their fates in the mice that

(c) The Author(s). 2018 Open Access This article is distributed under the terms of the Creative Commons Attribution 4.0 International License (http://creativecommons.org/licenses/by/4.0/), which permits unrestricted use, distribution, and 
developed. It was found that the labeled cells formed multiple organs in chimeric mice suggesting that, when placed in the proper conditions, the cells could differentiate into multiple different lineages [7]. While our early animal studies $[6,8]$ and those of others and a series of case reports suggested that adult $\mathrm{CD} 34^{+}$stem cells could transdifferentiate to nonhematogenous cell types when transplanted into adults, this remains controversial because of findings of fusion of $\mathrm{CD} 34^{+}$ stem cells with tissue-specific cells (reviewed in Porada et al. [9]) and findings suggesting that CD34 is a common marker of diverse progenitors (reviewed in Sidney et al. [10]). The current study was undertaken to determine whether $\mathrm{CD}_{3} 4^{+}$stem cells that could be induced to express embryonic germ layer lineage genes could be obtained from mobilized human peripheral blood, whether the cells so generated expressed proteins not expected in hematogenous stem cells in conditions where cell fusion was not possible, and whether gene expression could be modulated by culture conditions.

\section{Methods \\ Cells}

Human buffy coat cells and CD34 ${ }^{+}$cells from peripheral blood were purchased from ALLCELLS (Alameda, CA, USA). Human buffy coat cells were obtained by differential centrifugation of blood from normal donors. The human $\mathrm{CD}_{34}{ }^{+}$cells had been mobilized by the company by injecting donors with five daily injections of granulocyte macrophage colony-stimulating factor (GCSF). Blood was then collected and $\mathrm{CD} 34^{+}$cells were obtained by flow cytometry. We received $1 \times 10^{6} \mathrm{CD} 34^{+}$ hematopoietic stem cells pooled from multiple donors that were put directly into culture as described below.

Human bone marrow cells were purchased from a commercial vendor (Lonza, Inc., Walkersville, MD, USA) and separated by differential centrifugation as described previously [6]. $\mathrm{CD}^{+} 4^{+}$cells were grown as described below.

Blood was obtained from $\mathrm{C} 57 \mathrm{Bl} / 6 \mathrm{~J}$ mice by cardiac puncture, buffy coats obtained by differential centrifugation, and $\mathrm{CD}_{34}{ }^{+}$stem cells grown as described below. All procedures were performed in accordance with the approved University of Maryland School of Medicine Institutional Animal Care and Use Committee Protocol. National Institutes of Health guidelines for animal treatment and care were followed assiduously.

\section{Cell culture}

Human $\mathrm{CD}_{3} 4^{+}$stem cells were cultured from bone marrow-derived buffy coat or in situ mobilized CD34 ${ }^{+}$ bone marrow stem cells by culture in GIBCO Hybridoma serum-free medium and GIBCO protein-free medium each supplemented with $10 \mathrm{ng} / \mathrm{ml}$ human interleukin (IL)-3, $5 \mathrm{ng} / \mathrm{ml}$ human IL-6, $10 \mathrm{ng} / \mathrm{ml}$ human stem cell factor (SCF), and $\beta$-mercaptoethanol in T75 tissue culture flasks as reported previously [6]. Only suspended cells were retained at each passage; cells adherent to the flask were discarded. At each passage $2 \times 10^{6}$ suspension cells were replated in a new T75 flask. No feeder cells or matrix were employed.

To investigate whether culture conditions could be used to modulate gene expression in mobilized human $\mathrm{CD} 4^{+}$stem cells obtained from blood, after 14 days of culture in serum-free hybridoma medium supplemented with IL-3, IL-6, SCF, and $\beta$-mercaptoethanol the human peripheral blood $\mathrm{CD}^{+} 4^{+}$cells were switched to STEMdiff Neural Induction medium (STEMCELL Technologies, Vancouver, BC, Canada), a medium developed to induce human embryonic stem cells and human induced pluripotent stem cells to become neural stem cells. Cells were cultured in T75 flasks without feeder cells or matrix and remained viable until used on day 4 of culture.

To investigate whether the insulin found in the culture medium of CD34 $4^{+}$stems cells was produced by the stem cells (and not carried over from the medium), cells were cultured using the SILAC metabolic labeling system (ThermoFisher Scientific) containing ${ }^{13}$ C-leucine. Culture supernatants were collected and centrifuged for analysis by mass spectrometry.

Mouse $\mathrm{CD}^{+} 4^{+}$stem cells were cultured from peripheral blood buffy coats in $10 \mathrm{ml}$ GIBCO DMEM/ $10 \%$ fetal bovine serum supplemented with $10 \mathrm{ng} / \mathrm{ml}$ mouse IL-3, $5 \mathrm{ng} / \mathrm{ml}$ mouse IL-6, $10 \mathrm{ng} / \mathrm{ml}$ mouse SCF, and $\beta$-mercaptoethanol, the growth medium developed to grow $\mathrm{CD} 4^{+}$hematopoietic progenitors from adult mouse bone marrow. The cells were cultured in T75 tissue culture flasks as reported [6] with only suspension cells being retained at each passage with $2 \times 10^{6}$ suspension cells being replated in a new T75 flask. No feeder cells or matrix were employed.

\section{Quantitative polymerase chain reaction}

Quantitative polymerase chain reaction (PCR) was carried out using total RNA according to the methods given in the Additional file 1 with the primers listed in Table 1.

\section{Immunocytochemistry}

Immunocytochemistry was carried out by standard methodology using the following antibodies: CD34 (Pharmingen, 553731), cKit (Cymbus Biotechnology, CBL1359), CD45 (Pharmingen, 553076), Oct-4 (Santa Cruz, sc-9081), Sox-2 (Santa Cruz, sc-20088), LIN28 (Santa Cruz, sc-67266), Pax-6 (Santa Cruz, sc-11357), neurofilament H (Sternberger Monoclonals, SMI 312), Tuj1 (Covance, PRB435P and MMS435P), PLP (Chemicon, 
Table 1 Primers used for quantitative polymerase chain reaction

\begin{tabular}{|c|c|c|}
\hline & Forward & Reverse \\
\hline CD34 (99 bp) & 5'GCAGGTAAACTCCTGTCCTITA3' & 5'TTCTCCAGACCTTGGCTTC3' \\
\hline Neurofilament-H (149 bp) & 5'GAGGGTCTCCTCTGACG3' & 5'CTTGGCAGTGAGAGGGT3' \\
\hline Oct 4 (96 bp) & 5'CCCTCTAAGGAGTATCCCTGAA3' & 5'CTCAAAGCATCTTCTCCCTCTC3' \\
\hline Pdx 1 (109 bp) & 5'ТССТСТТССТССТССТСТТТС' & 5'GTAGTGAAGTGTGCAGCTAGAG3' \\
\hline Pax 6 (98 bp) & 5'GCGGAAGCTGCAAAGAAATAG3' & 5'GGGCAAACACATCTGGATAATG3' \\
\hline MOG (107 bp) & 5'TCTCTAGGGTGGTTCATCTCTAC3' & 5'TCCCTCACCAATAGCATCTTTC3' \\
\hline Tuj-1 (112 bp) & 5'CGAAGCCAGCAGTGTCTAAA3' & 5'GGAGGACGAGGCCATAAATAC3' \\
\hline cKit (109 bp) & 5'GATTCCCAGAGCCCACAATAG3' & 5'GGTGGCCCAGATGAGTTTAG3' \\
\hline Villin (95 bp) & 5'GCTGTCTGCCCTAGTTCATATC3' & 5'TGGGCATGGGTGCTITATT3' \\
\hline SOX-2 (76 BP) & 5'AGACGCTCATGAAGAAGGATAAG3' & 5'CCGCTCGCCATGCTATT3' \\
\hline LIN-28 (97 BP) & 5'CAGAGTGGAGAAAGTGGGAATAG3' & 5'CTAGAGGGAAGAAAGGGTGATG3' \\
\hline NG2 (102 bp) & 5'AACCAGGGTAACCTCCTACA3' & 5'TCСTTСTCСTTGСССТСТTA3' \\
\hline PLP (111 bp) & 5'CTCCAACCTTCTGTCCATCTG3' & 5'ATGAAGGTGAGCAGGGAAAC3' \\
\hline MBP & 5'GAAGGCCAGAGACCAGGATT3' & 5'AATTTGGAAAGCGTGCCCT3' \\
\hline GCK & 5'CCAACGGGGCCATGAATATG3' & 5'TCCTTGCTTTGTCCCTCCAT3' \\
\hline PTF 1a (75 bp) & 5'AGCAGGACACTCTCTCTCAT3' & 5'CAGACTTTGGCTGTTCGGATA3' \\
\hline GLUT2 & 5'TGGCCATTACTAACACGCATTG3' & 5'TGCTAAGCTITTGGGACCCA3' \\
\hline Proinsulin & 5'AGATCACTGTCCTTCTGCCA3' & 5'CGCACAGGTGTTGGTTCA3' \\
\hline Insulin & 5'TCAGAAGAGGCCATCAAGCA3' & 5'TGGCAGAAGGACAGTGATCT3' \\
\hline GAPDH (96 bp) & 5'TCTTTCTTTGCAGCAATGCC3' & 5'CCATGAGTCCTTCCACGATAC3' \\
\hline$\beta$-Actin (92 bp) & 5'CTTCCTTCCTGGGCATGG3' & 5'GTACAGGTCTITGCGGATGT3' \\
\hline
\end{tabular}

MAB388), NG2 (Chemicon, AB5320), MBP (from BP), MOG (Millipore, MAB345), Pdx1 (Chemicon, AB3243), Ptf1 $\alpha$ (R\&D Systems, AF6119), glucokinase (Santa Cruz, sc7908), insulin A (Santa Cruz, sc-7839), insulin B (Santa Cruz, sc-7838), and villin (Santa Cruz, sc-7672).

\section{Immunofluorescence staining}

Immunofluorescence staining was performed according to the methods given in the Supplemental Materials and Methods (Additional file 1).

\section{Western blot analysis}

Western blot analyses were conducted via standard methodology using the antibodies listed above in section 2.4 (Immunocytochemistry).

\section{Mass spectrometry \\ Analysis of insulin peptides from human mobilized $C D 34^{+}$ stem cells grown in protein-free medium}

Mass spectrometry was performed by the Protein Analysis Laboratory, Center for Vascular and Inflammatory Diseases, University of Maryland School of Medicine. The proteins from the conditioned media were captured by solid-phase extraction using TARGA C18 MicroSpin tips (The Nest Group, Southborough, MA, USA). After acidifying the conditioned media with trifluoroacetic acid to a final concentration of $0.1 \%$, it was passed through the MiniSpin tips, washed with 10 column volumes of $0.1 \%$ trifluoroacetic acid, and proteins were eluted with $70 \%$ acetonitrile containing $0.1 \%$ trifluoroacetic acid. The eluted fraction was evaporated to dryness in a centrifugal evaporator and subsequently dissolved in $100 \mu 100$ mM triethylammonium bicarbonate, $\mathrm{pH}$ 8.5, containing $2 \%$ sodium deoxycholate. Disulfide bonds were reduced with $5 \mathrm{mM}$ dithiothreitol at $37{ }^{\circ} \mathrm{C}$ for $30 \mathrm{~min}$ followed by alkylation of the sulfhydryl groups with chloroacetamide at room temperature in the dark. After neutralization of residual chloroacetamide by the addition of DTT, proteins were digested overnight at $37{ }^{\circ} \mathrm{C}$ with Trypsin/LysC (Promega, Madison, WI, USA) at a final concentration of $12.5 \mathrm{ng} / \mu \mathrm{l}$ of the enzyme mixture. The digested sample was acidified with trifluoroacetic acid to a final concentration of $1 \%$ and the precipitated sodium deoxycholate was removed by centrifugation at $10,000 \times \mathrm{g}$ for $5 \mathrm{~min}$. The peptides were recovered from the supernatant by solid-phase extraction using the TARGA C18 MicroSpin tips as described above and subsequently analyzed by liquid chromatography tandem mass spectrometry (MS/MS). Peptides were separated by reversed phase high-performance liquid chromatography (HPLC) on an in-house pulled-tip fused silica (Molex PolyMicro Technologies) capillary 
column $(0.1 \mathrm{~mm} \times 150 \mathrm{~mm})$ packed with TARGA C18 $3 \mu$ stationary phase connected to a Surveyor HPLC pump (Thermo Scientific) operated at $200 \mu \mathrm{l} / \mathrm{min}$ and set up to deliver a split flow to the capillary column at $\sim 0.45 \mu \mathrm{l} / \mathrm{min}$. Electrospray was initiated by application of $1800 \mathrm{~V}$ at the head of the column via a liquid junction. Gas phase ions were analyzed in an LTQ Orbitrap mass spectrometer (Thermo Scientific) using a duty cycle of one full scan followed by MS/MS scans on up to 12 of the most abundant ions, above a preset threshold, observed in the preceding full scan. These data were analyzed with Proteome Discoverer 1.4 (Thermo Scientific) using the Sequest HT search engine to match acquired spectra against a human subset of the Uniprot protein sequence database, which included sequences of common protein contaminants. Percolator was used to validate peptide-spectrum matches at a $Q$ value [11] (false discovery rate (FDR)) of 0.01 .

\section{Analysis of insulin peptides labeled with ${ }^{13} \mathrm{C}$-leucine from human mobilized $\mathrm{CD} 34^{+}$stem cells grown in SILAC medium} Mass spectrometry was performed at the University of Maryland School of Pharmacy Mass Spectrometry Center. Tryptic peptides were separated on a Waters nanoACQUITY UPLC system with a 20-cm ACQUITY UPLC M-Class CSH C18 column by a $3-43 \%$ acetonitrile gradient in $0.1 \%$ formic acid over $180 \mathrm{~min}$ at a flow rate of $400 \mathrm{~nL} / \mathrm{min}$, and were analyzed on a coupled Thermo Scientific Orbitrap Fusion Tribrid mass spectrometer as described [12]. Tandem mass spectra were searched against human insulin chain A and chain B sequences using SEQUEST HT algorithm with a precursor tolerance of $5 \mathrm{ppm}$ and a product tolerance of $0.5 \mathrm{Da}$. ${ }^{13} \mathrm{C}$-labeled leucine was treated as a variable modification, and cysteine carbamidomethylation was treated as a fixed modification.

\section{Results}

A subset of mobilized human and mouse CD34 ${ }^{+}$stem cells grow exponentially in vitro

We determined the growth rates of mobilized human peripheral blood CD34 ${ }^{+}$stem cells and in situ bone marrow $\mathrm{CD} 4^{+}$stem cells. The mobilized $\mathrm{CD} 34^{+}$stem cells from peripheral blood grew exponentially at the same rate as $\mathrm{CD}^{+} 4^{+}$cells from adult human bone marrow (Fig. 1). The slopes of the growth curves for both human bone marrow $\mathrm{CD}^{+} 4^{+}$cells and human mobilized peripheral blood $\mathrm{CD} 4^{+}$cells were equivalent. Similarly, in the adult mouse, the $\mathrm{CD}_{3} 4^{+}$stem cells in $\mathrm{C} 57 \mathrm{Bl} / 6 \mathrm{~J}$ adult mouse peripheral blood grew exponentially at the same rate as $\mathrm{CD}^{+} 4^{+}$cells from adult $\mathrm{C} 57 \mathrm{Bl} / 6 \mathrm{~J}$ bone marrow (Fig. 1). The slopes of the growth curves for both mouse bone marrow CD34 ${ }^{+}$cells and mouse peripheral blood CD $34^{+}$ cells were indistinguishable.

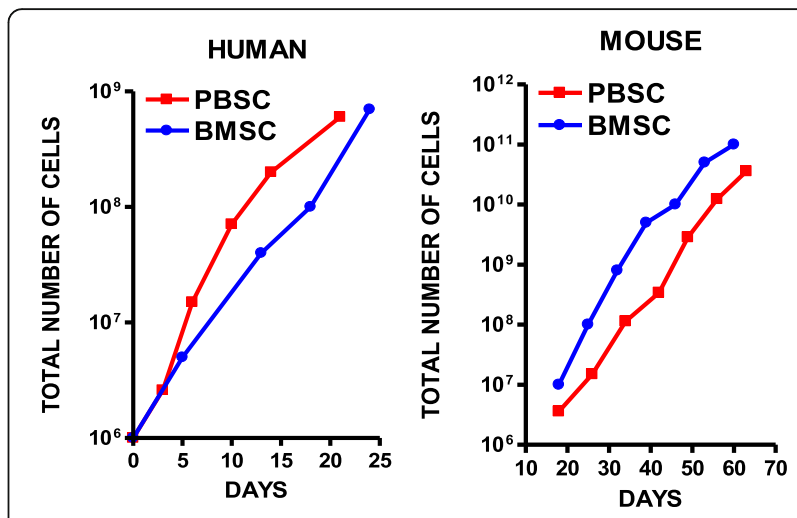

Fig. 1 Human and mouse mobilized $\mathrm{CD} 34^{+}$bone marrow stem cells grow exponentially in vitro. Mobilized human CD34 ${ }^{+}$peripheral blood stem cells (PBSC) grew exponentially in vitro at the same rate as human $\mathrm{CD}_{4}{ }^{+}$cells in bone marrow (BMSC). Similarly, mouse CD34 ${ }^{+}$ cells from peripheral blood (PBSC) grew exponentially in vitro at the same rate as human $\mathrm{CD} 34^{+}$cells in bone marrow (BMSC). The results are shown for human and mouse cells from one of three experiments, each of which gave similar results

\section{Differences in $\mathrm{CD} 34^{+}$stem cells between human and mouse peripheral blood}

We were able to culture $\mathrm{CD}^{+} 4^{+}$stem cells from mouse peripheral blood buffy coat, but we were not able to grow $\mathrm{CD}^{+} 4^{+}$bone marrow stem cells from commercial human nonmobilized blood buffy coat or from purified human nonmobilized peripheral blood mononuclear cells. We were able to culture $\mathrm{CD} 34^{+}$stem cells from mobilized human peripheral blood (Fig. 1). The $\mathrm{CD}_{4} 4^{+}$stem cell cultures from mobilized human peripheral blood differed from those obtained from the mouse in that, while the latter contained a single spherical cell morphology, the former contained four morphological phenotypes: one cell type that was adherent to the plastic flask, and three cell types that grew in suspension-a spherical cell, a cone-shaped cell, and a minute cell. All four cell types persisted throughout the culture period, although only the nonadherent cells were passaged in culture. The three nonadherent subtypes were harvested for analysis in the experiments that followed.

\section{Gene expression by a subset of mobilized human peripheral blood $\mathrm{CD}^{+} 4^{+}$cells}

Gene expression by the mobilized $\mathrm{CD}_{3} 4^{+}$cells from human peripheral blood, grown in culture for 15 days, was examined by quantitative PCR. The cultured human $\mathrm{CD}_{4}{ }^{+}$cells expressed: the hematopoietic stem cell genes CD34 and cKit; the embryonic stem cell genes Oct-4, Sox-2, and Lin28; the neural stem cell gene Pax-6; the neuronal genes neurofilament $\mathrm{H}$ and tubulin (Tuj-1); the oligodendroglial genes NG2, MOG, PLP, and MBP; the pancreatic genes Pdx1, Ptfla, GLUT2, glucokinase, proinsulin, and insulin; and the intestinal gene villin at the mRNA level (Fig. 2). 


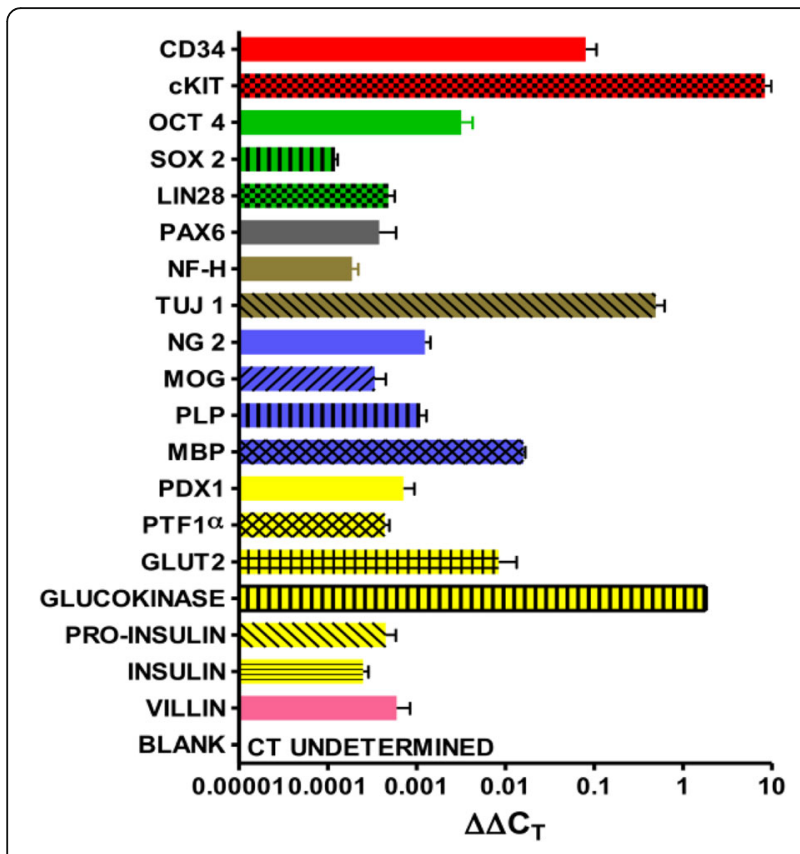

Fig. 2 Human mobilized $\mathrm{CD}_{3} 4^{+}$bone marrow stem cells express mRNAs of embryonic stem cell genes and embryonic germ layer lineage genes. Quantitative PCR analysis of mRNA expression by the human mobilized $\mathrm{CD}_{3} 4^{+}$stem cells revealed expression of hematopoietic stem cell genes (red bars), ESC genes (green bars), neural stem cell genes (gray bar), neuronal genes (brown bars), oligodendrocyte genes (blue bars), pancreatic genes (yellow bars), and intestinal genes (pink bar). The results shown are from one of two experiments with each sample run in triplicate

Western blot analysis of protein expression by a subset of human mobilized $\mathrm{CD} 34^{+}$bone marrow stem cells

After 21 days of culture, the mobilized human peripheral blood $\mathrm{CD}^{+} 4^{+}$cells were examined by Western blot analysis (Fig. 3). The mobilized cells expressed embryonic stem cell (ESC) Sox2 and LIN28 proteins, the neuronal neurofilament protein SMI312, oligodendroglial PLP, NG2, and MBP proteins, pancreatic glucokinase and preproinsulin protein, and intestinal villin protein (Fig. 3). A difference between human and mouse mobilized CD34 ${ }^{+}$ stem cells is that human $\mathrm{CD}^{+} 4^{+}$cells express MBP and insulin mRNA and protein, whereas mouse CD34 ${ }^{+}$cells do not.

Human and mouse mobilized $\mathrm{CD}_{3} 4^{+}$stem cells uniformly express ESC and germ layer lineage genes in vitro Immunocytochemistry revealed that all human $\mathrm{CD} 34^{+}$ cells in vitro expressed the embryonic stem cell protein LIN28. Double labeling showed that the CD34 ${ }^{+}$cells also exhibited neuronal neurofilament $\mathrm{H}$ and tubulin (Tuj1). Double labeling also demonstrated that the $\mathrm{CD}_{4} 4^{+}$cells expressed oligodendrocyte NG2 and PLP. In addition, double labeling revealed that the human $\mathrm{CD}_{4} 4^{+}$cells express pancreatic Ptf-1a and intestinal villin. In all cases, the four human $\mathrm{CD}^{+} 4^{+}$cell morphological phenotypes (adherent, suspension spherical, conical, and minute) exhibited staining for each protein (Fig. 4a). The phenotype of mouse CD34 ${ }^{+}$ cells grown from blood was the same as that for those $\mathrm{CD}_{3}{ }^{+}$cells grown from bone marrow for all representative genes tested. Previously, we reported that mouse bone marrow cells expressed: the ESC markers Oct-4, Sox-2, and LIN28; the bone marrow stem cell markers CD34 ${ }^{+}$, cKit, and CD45; neural stem cell (NSC) and neuronal markers Pax-6, neurofilament $\mathrm{H}$, and tubulin; the oligodendroglial markers NG2, PLP, and MOG; and the pancreatic markers Pax-6, Ptfla, and $\mathrm{Pdx}-1$. These markers were reported to be present in CD $34^{+}$cells cultured from mouse bone marrow $[5,6]$. Here, we show that these genes are also expressed in $\mathrm{CD} 4^{+}$cells cultured from mouse peripheral blood (Fig. 4b). Thus, in mobilized human $\mathrm{CD}^{+} 4^{+}$stem cells and mouse peripheral blood $\mathrm{CD} 34^{+}$stem cells cultured in vitro, immunocytochemistry showed that all cells in culture expressed each of the proteins tested.

\section{Gene expression in a subset of human peripheral blood $\mathrm{CD} 4^{+}$can be modulated by culture conditions}

After 14 days in culture in serum-free hybridoma medium supplemented with IL-3, IL-6, SCF, and $\beta$ mercaptoethanol, the human peripheral blood $\mathrm{CD}_{4} 4^{+}$ cells were switched to STEMdiff Neural Induction medium (STEMCELL Technologies). STEMdiff medium was developed to induce human embryonic stem cells and human induced pluripotent stem cells to become neural stem cells. We compared mRNA expression of human mobilized peripheral blood $\mathrm{CD} 4^{+}$cells after 4 days of culture in STEMdiff Neural Induction medium by quantitative PCR (Fig. 5). Figure compares gene expression in serum-free hybridoma medium supplemented with IL-3, IL- 6, SCF, and $\beta$-mercaptoethanol with gene expression in STEMdiff Neural Induction medium for 4 days. The level of hematopoietic stem cell (HSC) CD34 expression was virtually unchanged in STEMdiff medium, whereas cKit was markedly reduced 5000-fold. The ESC marker Oct-4 was elevated 20-fold in STEMdiff medium, Sox-2 was increased 1000-fold, and LIN28 was increased 500-fold. The NSC marker Pax-6 was increased 10 -fold in STEMdiff medium. Neuronal neurofilament $\mathrm{H}$ was increased 50-fold, whereas tubulin was virtually unchanged in STEMdiff medium. Oligodendroglial NG-2 was increased 350-fold, MOG was increased 500-fold, and PLP was virtually unchanged, while MBP increased 10fold in STEMdiff medium. Intestinal villin was increased 500-fold in STEMdiff medium. Pancreatic Pax6 was increased 10-fold, Pdx-1 was increased 200-fold, and Ptf1a was increased 500-fold, while GLUT-2 increased 10-fold, glucokinase was virtually unchanged, proinsulin increased 


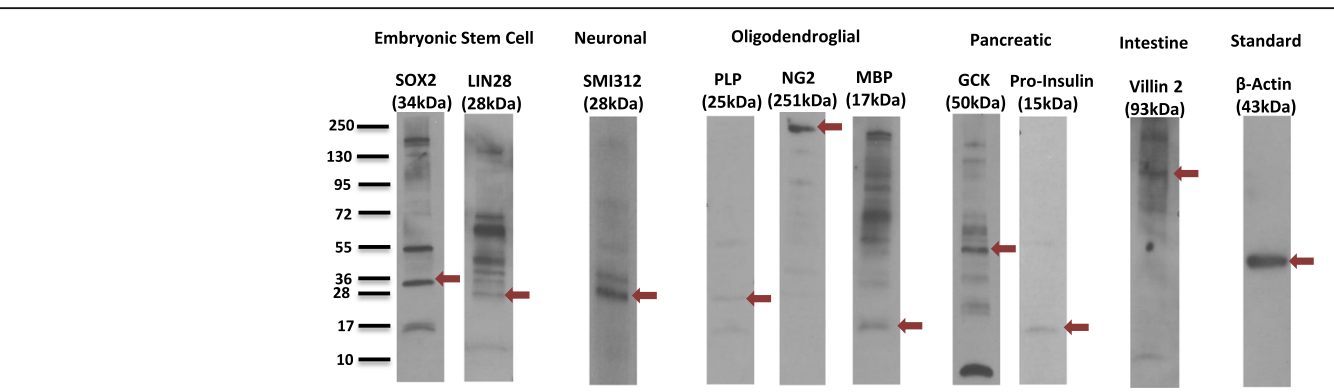

Fig. 3 Human mobilized CD34 ${ }^{+}$bone marrow stem cells express proteins of embryonic stem cell genes and embryonic germ layer lineage genes. Western blot analyses revealed that the human mobilized $\mathrm{CD} 34^{+}$stem cells express embryonic stem cell, neuronal, oligodendroglial, pancreatic, and intestinal proteins. Each sample was run twice and the results are representative

100-fold, and insulin increased 100-fold in STEMdiff medium. In summary, culture of human CD $34^{+}$stem cells in the neural induction medium led to increases in the expression of the genes studied except for cKIT and glucokinase, which were decreased, and Tuj1 and PLP which were not significantly different.

\section{A subset of human mobilized $\mathrm{CD} 34^{+}$stem cells synthesize insulin}

Mobilized human $\mathrm{CD}^{+} 4^{+}$stem cells that were growing in serum-free GIBCO Hybridoma serum-free cell culture medium, supplemented with human IL-3, IL- 6, SCF, and $\beta$-mercaptoethanol, were washed twice in $15 \mathrm{ml}$ protein-free medium to remove the insulin present in the serum-free medium. The cells were then cultured in GIBCO protein-free medium supplemented with IL3, IL 6 , SCF, and $\beta$-mercaptoethanol. After 5 days in culture the cells were removed from the medium by centrifugation. The cell culture medium was then analyzed by mass spectrometry for insulin. Three peptides of human insulin were revealed by mass spectrometry: two beta chain peptides, VEALYLVCGER (Fig. 6a) and a
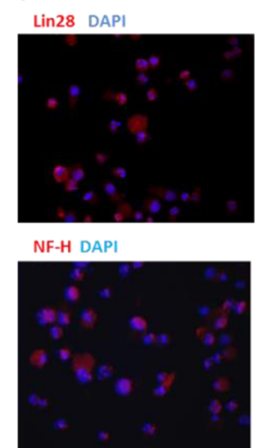

PLP DAPI

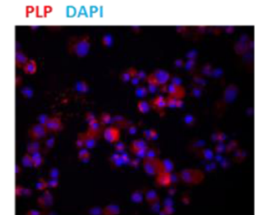

Ptf1a DAPI

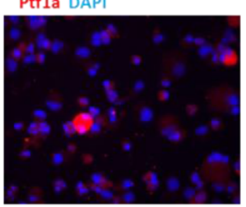

Tuj DAPI

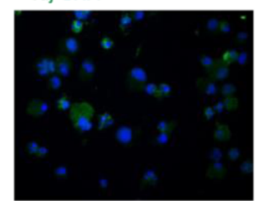

NG2 DAPI

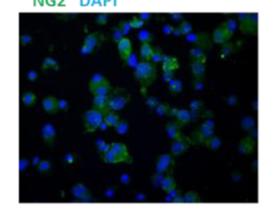

Villin DAPI

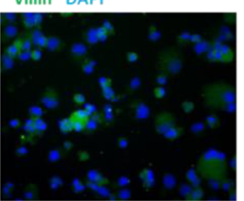

b

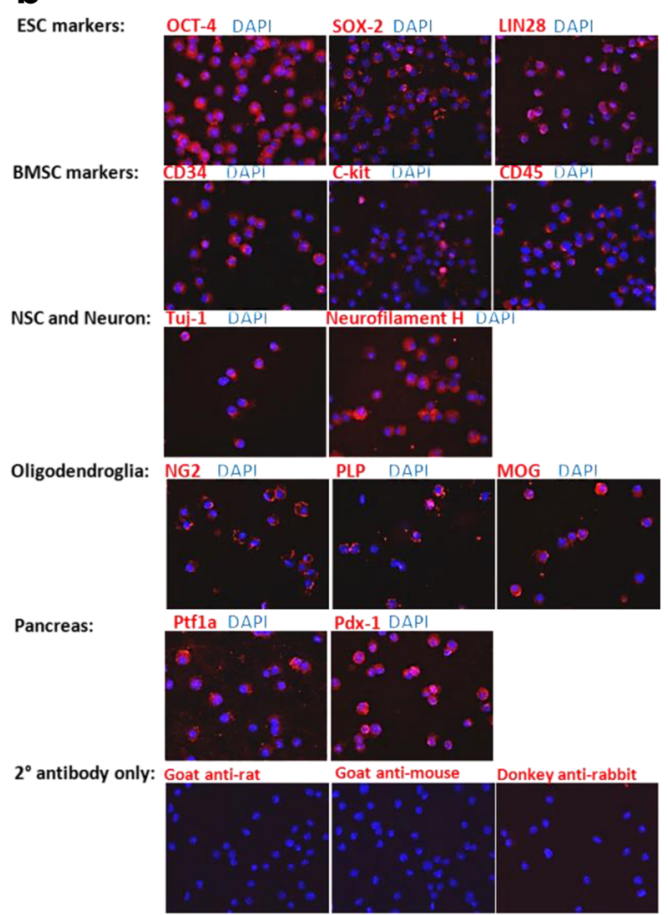

Fig. 4 All human and mouse mobilized CD34+ bone marrow stem cells exhibit embryonic stem cell (ESC) and germ layer lineage proteins in vitro. Immunocytochemistry of mobilized human (a) and mouse (b) CD34 ${ }^{+}$cells in culture show that all human and mouse cells expressed ESC and germ layer lineage proteins. DAPI (blue) cell nuclear staining indicates all of the nucleated cells in each field. The results given for human are representative of two experiments, and for mouse of three experiments. BMSC, bone marrow stem cell; NSC, neural stem cell 


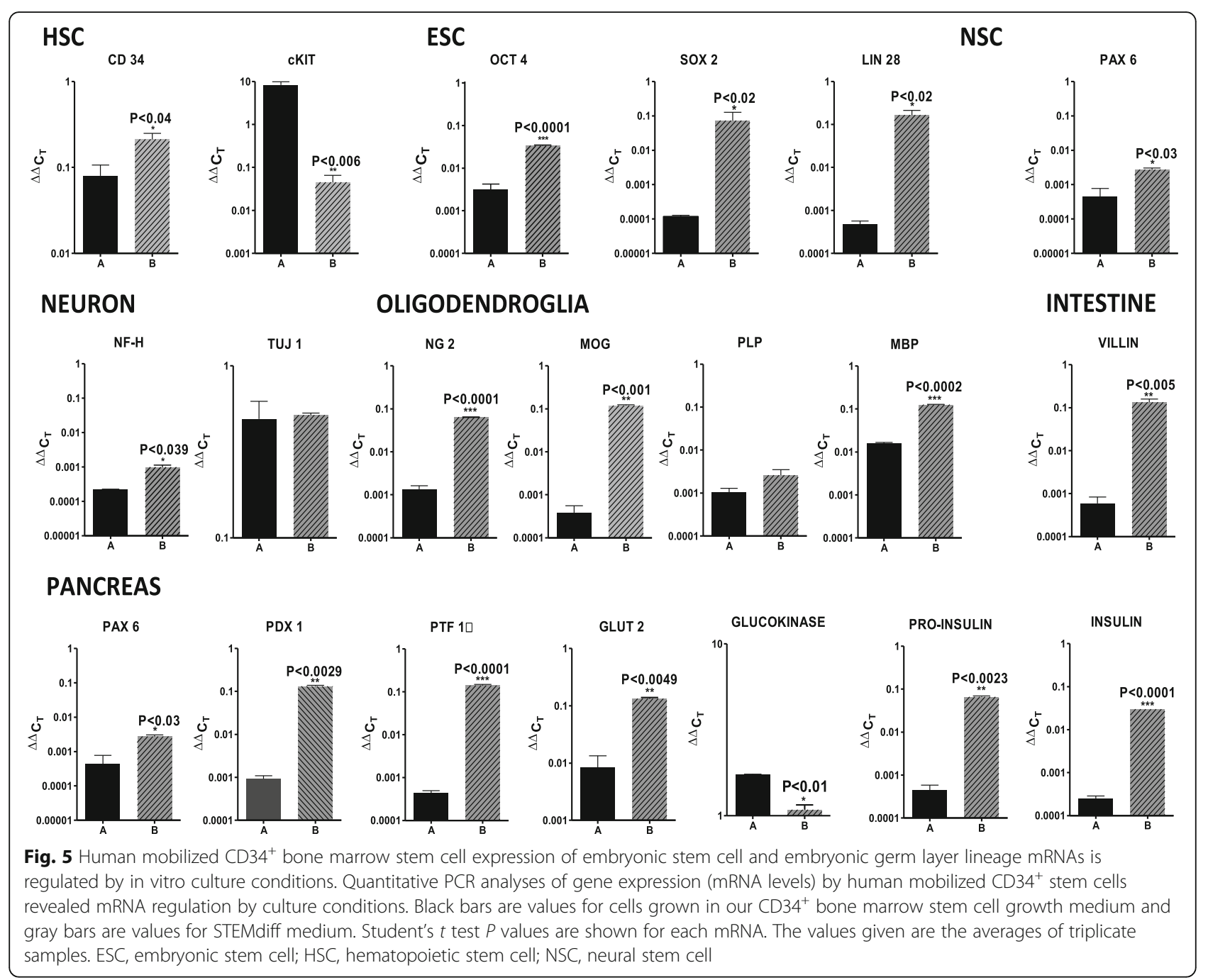

EALYVCGER (Fig. 6b), and one alpha-chain peptide, GIVEQCCTICSL (Fig. 6c). To determine whether the insulin that was detected was synthesized by the cells and not carried over from the medium, medium from cells cultured in metabolic labeling medium with ${ }^{13} \mathrm{C}$-leucine was analyzed by mass spectrometry. The beta chain peptide FVNQHLCGSHLVEALYLVCGER was identified with the label at the first and second leucines. These results suggest the $\mathrm{CD} 34^{+}$cells synthesize insulin under the conditions described.

\section{Discussion}

The potential of stem cells as cell replacement therapy for degenerative disease and other types of tissue injury has been complicated by the ethical issues surrounding the use of embryonic stem cells [13], the histocompatibility issues of tissue-specific stem cells from other individuals [14], the difficulty obtaining large quantities of inducible pluripotent stem cells [15], and teratoma formation by both embryonic and inducible pluripotent stem cells [16]. Early reports from mouse studies and studies of human transplant recipients suggesting the possibility that hematopoietic stem cells could transdifferentiate into cells of other types including neural cells [17-21], cardiac cells [22-24], hepatic cells [25-28], and pancreatic cells $[29,30]$ sparked interest in hematogenous stem cells for cell replacement therapy. Subsequently a population of very small embryonic-like (VSEL) stem cells was identified as a possible circulating pluripotent stem cell $[31,32]$. More recently, this enthusiasm has been tempered by evidence that at least some of the observations were due to cell fusion [9], the presence of CD34 antigen on progenitor cells not of hematogenous origin [10], and the failure to confirm the findings regarding VSEL stem cells [33]. While we were able to exclude cell fusion as an explanation in our earlier work suggesting that $\mathrm{CD}^{+} 4^{+}$stem cells could transdifferentiate into multiple lineages when placed into mouse blastocysts [7], in studies showing transdifferentiation into oligodendroglial cells which 


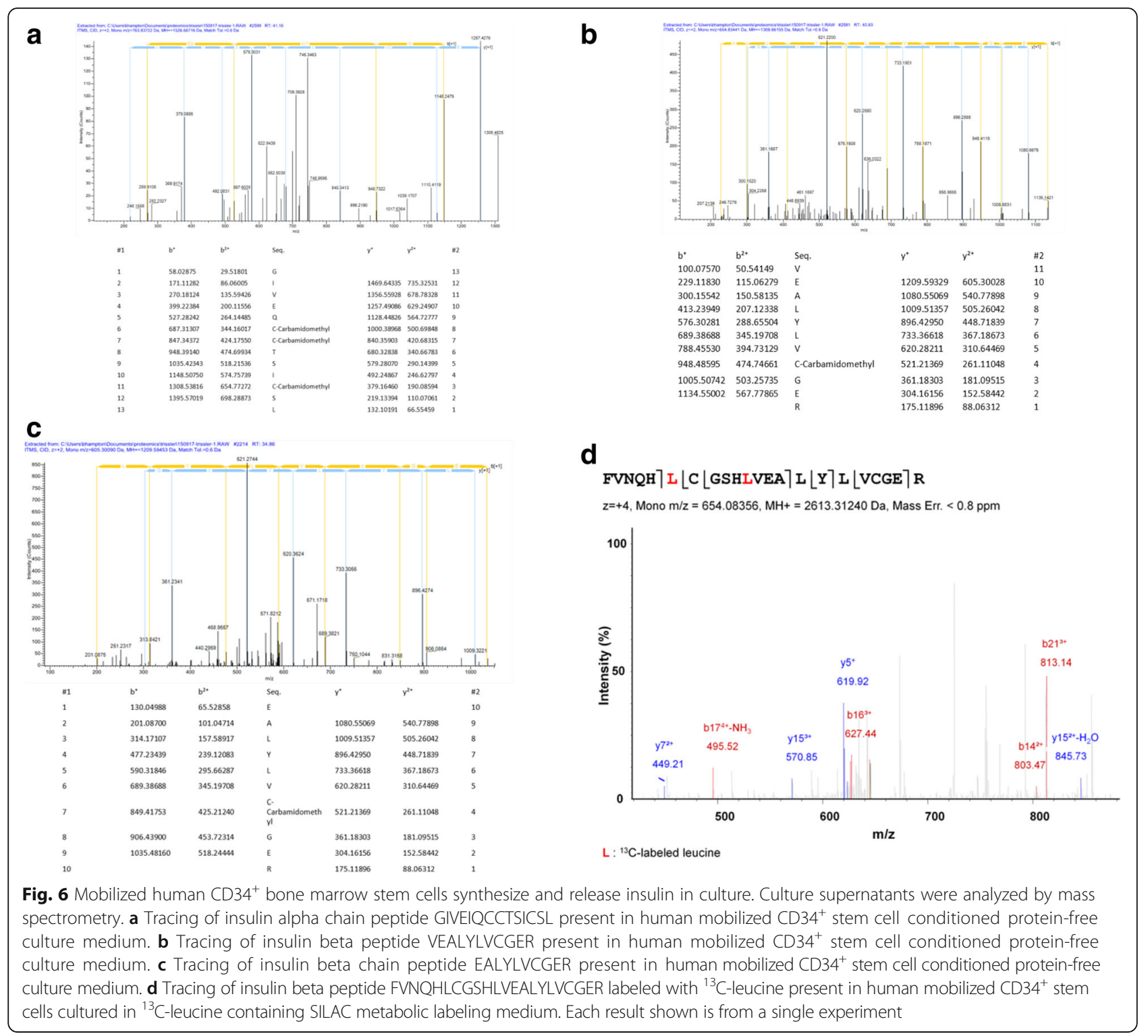

ensheath axons in Shiverer mice [8] we did not fully exclude the possibility of cell fusion. We did identify a small cell morphology in cultured cells from mobilized human blood that might correspond with the previously reported VSEL stem cells [31], but we did not attempt to separate or test the cells separately with that morphology. Therefore, it was important to demonstrate that gene expression by the $\mathrm{CD}_{3} 4^{+}$cells can be modulated (in this case by culture conditions) and that the $\mathrm{CD}_{34}{ }^{+}$cells express genes characteristic of differentiated tissues (in this case insulin). The current results show both that gene expression by the $\mathrm{CD} 34^{+}$ cells can be modulated by culture conditions and that the $\mathrm{CD} 34^{+}$cells can translate and transcribe the gene for insulin in conditions where cell fusion with pancreatic cells was not possible. These findings support the idea that this subpopulation of $\mathrm{CD} 34^{+}$stem cells might either be at a stage prior to commitment to the hematogenous lineage or be capable of transdifferentiation from that lineage to other lineages. Further work is needed to determine this.

If these $\mathrm{CD}_{3} 4^{+}$stem cells are shown to be capable of differentiating into other cells types, then the practical issue of their availability would be important. We have shown previously that, although the cells could be obtained from mouse bone marrow and peripheral blood, we could obtain them from human bone marrow but not peripheral blood. Our results in the current study showing that the cells can be obtained from mobilized peripheral blood would allow for a practical method for obtaining large numbers of cells should they be found useful in cell replacement therapy or for other purposes. 


\section{Conclusions}

Mobilized human $\mathrm{CD}_{3} 4^{+}$bone marrow stem cells constitutively express an array of ESC and embryonic germ layer lineage genes. Gene expression can be modulated by modifying culture conditions, and the cells synthesize insulin. These results suggest a practical source of autologous stem cells for studies to determine whether they might be useful in cell replacement therapy.

\section{Additional file}

Additional file 1: Supplemental materials and methods. (DOCX $17 \mathrm{~kb}$ )

\section{Acknowledgements}

The authors would like to thank Deborah Yarnell for technical assistance and Mohammed I. Arvas for his assistance with manuscript revisions.

\section{Funding}

This work was supported by funding from the Department of Veterans Affairs to PSF and CTB. Additional support was provided by the University of Maryland, School of Pharmacy Mass Spectrometry Center (SOP1841-IQB2014).

\section{Availability of data and materials}

Data will be made available according to the Department of Veteran's Affairs policies on data use and sharing.

\section{Authors' contributions}

BP and DT designed the study; TM, PSF, BP, CTB, and DT provided resources for the study; TM, VKN, PRG, BH, WH, MAK, and DT performed the experiments; TM, CTB, BH, WH, MAK, and DT analyzed the data; TM, BH, WH, MAK, PSF, CTB, and DT co-wrote the manuscript. All authors reviewed the galley proofs and, with the inclusion of the corrections I am submitting now, have approved the final manuscript.

\section{Ethics approval}

All procedures were performed in accordance with an approved University of Maryland School of Medicine Institutional Animal Care and Use Committee Protocol. National Institutes of Health guidelines for animal treatment and care were followed assiduously.

\section{Competing interests}

DT and CTB hold US (US 8,940,535 B2) and International (PTC/US04/37122) patents.

\section{Publisher's Note}

Springer Nature remains neutral with regard to jurisdictional claims in published maps and institutional affiliations.

\section{Author details}

'Department of Neurology, University of Maryland School of Medicine, Baltimore, MD 21201, USA. ${ }^{2}$ Multiple Sclerosis Center of Excellence, East VA Maryland Health Care System, Baltimore, MD 21201, USA. ${ }^{3}$ VA Maryland

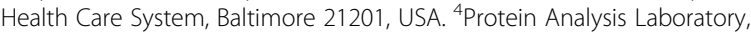
Center for Vascular and Inflammatory Diseases, University of Maryland School of Medicine, Baltimore, MD 21201, USA. ${ }^{5}$ University of Maryland School of Pharmacy, Department of Pharmaceutical Sciences, Baltimore, MD 21201, USA. ${ }^{6}$ Mass Spectrometry Center, University of Maryland School of Pharmacy, Baltimore, MD 21201, USA. ${ }^{7}$ CNRS UMR 8118, Université Paris Descartes, 45 rue des Saints-Pères, 75006 Paris, France. ${ }^{8}$ Académie Nationale de Médecine, 16 rue Bonaparte, 75006 Paris, France.
Received: 12 December 2017 Revised: 20 March 2018

Accepted: 2 April 2018 Published online: 02 May 2018

\section{References}

1. Spangrude GJ, Heimfeld S, Weissman IL. Purification and characterization of mouse hematopoietic stem cells. Science. 1988;241:58-62.

2. Berardi AC, Wang A, Levine JD, Lopez P, Scadden DT. Functional isolation and characterization of human hematopoietic stem cells. Science. 1995;267:104-8.

3. McKinney-Freeman SL, Naveiras O, Yates F, Loewer S, Philitas M, Curran M, Park PJ, Daley GQ. Surface antigen phenotypes of hematopoietic stem cells from embryos and murine embryonic stem cells. Blood. 2009:114:268-78.

4. Yu J, Thompson JA. Pluripotent stem cell lines. Genes Dev. 2008;22:1987-97.

5. Pessac B, Mehdi AA, Ford D, Patibandla GK, Trisler D. Hematopoietic progenitors express embryonic stem cell and germ layer genes. Comptes Rendus Biol. 2011;334:300-6.

6. Goolsby J, Marty MC, Heletz D, Chiappelli J, Tashko G, Yarnell D, Fishman PS, Dhib-Jalbut S, Bever CT, Pessac B, Trisler D. Hematopoietic progenitors express neural genes. Proc Natl Acad Sci USA. 2003;100:14926-31.

7. Pessac B, Nimmagadda VK, Makar T, Fishman PS, Bever Jr CT, Trisler D. Adult hematopoietic progenitors are multipotent in chimeric mice. Comptes Rendus Biol. 2012;335:454-62.

8. Goolsby J, Makar T, Dhib-Jalbut S, Bever C, Pessac BTD. Hematopoietic progenitors express myelin basic protein and ensheath axons in Shiverer brain. J Neuroimmunol. 2013:257:13-20.

9. Porada CD, Atala AJ, Almelda-Porada G. The hematopoietic system in the context of regenerative medicine. Methods. 2016:99:44-61.

10. Sidney LE, Branch MJ, Dunphy SE, Dua HS, Hopkinson A. Concise review: evidence for CD34 as a common marker for diverse progenitors. Stem Cells. 2014:32:1380-9.

11. Käll L, Storey JD, MacCoss MJ, Noble WS. Assigning confidence measures to peptides identified by tandem mass spectrometry. J Proteome Res. 2008; 7(1):29-34.

12. Williamson JC, Edwards AV, Verano-Braga T, Schwammle V, Kjeldsen F, Jensen ON, Larsen MR. High-performance hybrid Orbitrap mass spectrometers for quantitative proteomic analysis: observations and implications. Proteomics. 2016;16(6):907-14.

13. Lo B, Parham L. ethical issues in stem cell research. Endocr Rev. 2009:30(3): 204-13. https://doi.org/10.1210/er.2008-0031.

14. Adams AB, Williams MA, Jones TR, Shirasugi N, Durham MM, Kaech SM, Wherry EJ, Onami T, Lanier JG, Kokko KE, Pearson TC, Ahmed R, Larsen CP. Heterologous immunity provides a potent barrier to transplantation tolerance. J Clinical Invest. 2003;111(12):1887-95. https://doi.org/10.1172/ JCI200317477.

15. Medvedev SP, Shevchenko Al, Zakian SM. Induced pluripotent stem cells: problems and advantages when applying them in regenerative medicine. Acta Nat. 2010:2(2):18-28.

16. Gutierrez-Aranda I, Ramos-Mejia V, Bueno C, Munoz-Lopez M, Real PJ, Mácia A, Sanchez L, Ligero G, Garcia-Parez JL, Menendez P. Human induced pluripotent stem cells develop teratoma more efficiently and faster than human embryonic stem cells regardless the site of injection. Stem Cells (Dayton, Ohio). 2010;28(9):1568-70. https://doi.org/10.1002/stem.471.

17. Brazelton TR, Rossi FM, Keshet Gl, Blau HM. From marrow to brain: expression of neuronal phenotypes in adult mice. Science. 2000;290:1775-9.

18. Eglitis MA, Mezey E. Hematopoietic cells differentiate into both microglia and macroglia in the brains of adult mice. Proc Natl Acad Sci U S A. 1997:94:4080-5.

19. Mezey E, Chandross KJ, Harta G, Maki RA, McKercher SR. Turning blood into brain: cells bearing neuronal antigens generated in vivo from bone marrow. Science. 2000;290:1779-82

20. Cogle CR, Yachnis AT, Laywell ED, Zander DS, Wingard JR, Steindler DA et al. Bone marrow transdifferentiation in brain after transplantation: a retrospective study. Lancet. 2004;363:1432-7.

21. Borlongan CV. Bone marrow stem cell mobilization in stroke: a "bonehead" may be good after all. Leukemia. 2011;25:1674-86.

22. Wojakowski W, Tendera M, Kucia M, Zuba-Surma E, Paczkowska E, Ciosek J Hałasa M, Król M, Kazmierski M, Buszman P, Ochała A, Ratajczak J, Machaliński B, Ratajczak MZ. Mobilization of bone marrow-derived Oct-4+ SSEA-4+ very small embryonic-like stem cells in patients with acute myocardial infarction. J Am Coll Cardiol. 2009;53:1-9.

23. Quaini F, Urbanek K, Beltrami AP, Finato N, Beltrami CA, Nadal-Ginard B, Kajstura J, Leri A, Anversa P. Chimerism of the transplanted heart. New Engl J Med. 2002;346:5-15. 
24. Yeh ET, Zhang S, Wu HD, Korbling M, Willerson JT, Estrov Z. Transdifferentiation of human peripheral blood CD34+ enriched cell population into cardiomyocytes. Circulation. 2001;108:2070-3.

25. Petersen BE, Bowen WC, Patrene KD, Mars WM, Sullivan AK, Murase N, Boggs SS, Greenberger JS, Goff JP. Bone marrow as a potential source of hepatic oval cells. Science. 1999;284:1168-70.

26. Alison MR, Puolsom R, Jeffery R, Dhillon AP, Quaglia A, Jacob J, Novelli M, Prentice G, Williamson J, Wright NA. Hepatocytes from non-hepatic adult stem cells. Nature. 2000;406:257.

27. Theise ND, Nimmakayalu M, Gardner R, Illei PB, Morgan G, Teperman L, Henegariu O, Krause DS. Liver from bone marrow in humans. Hepatology. 2000;32:11-6.

28. Lagasse E, Connors H, Al-Dhalimy M, Reitsma M, Dohse M, Osbome L, Wang X, Finegold M, Weissman IL, Grompe M. Purified hematopoietic stem cells can differentiate into hepatocytes in vivo. Nat Med. 2000;6:1229-34.

29. Ianus A, Holz GG, Theise ND, Hussain MA. In vivo derivation of glucosecompetent pancreatic endocrine cells from bone marrow without evidence of cell fusion. J Clin Invest. 2003;111:843-50.

30. Lee RH, Seo MJ, Reger RL, Spees JL, Pulin AA, Olson SD, Prockop DJ. Multipotent stromal cells from human bone marrow home to and promote repair of pancreatic islets and renal glomeruli in diabetic NOD/scid mice. Proc Natl Acad Sci U S A. 2006:103:17438-43.

31. Kucia M, Reca R, Campbell FR, Zuba-Surma E, Majka M, Ratajczak J, Rtajczak MZ. A population of very small embryonic-like (VSEL) CXCR4+ SSEA-1+ Oct4+ stem cells identified in adult bone marrow. Leukemia. 2006;20:857-69.

32. Sovalat $\mathrm{H}$, Scrofani M, Eidenschenk A, Henon P. Human very small embryonic-like stem cells are present in normal peripheral blood of young, middle-aged and aged subjects. Stem Cells International. 2016:Article ID 7651645.

33. Myanishi M, Yasuo M, Seita J, Chen JY, Karten S, Chan CKF, Nakauchi H, Weissman IL. Do pluripotent stem cells exist in adult mice as very small embryonic stem cells? Stem Cell Reports. 2013;1:198-208.

\section{Ready to submit your research? Choose BMC and benefit from}

- fast, convenient online submission

- thorough peer review by experienced researchers in your field

- rapid publication on acceptance

- support for research data, including large and complex data types

- gold Open Access which fosters wider collaboration and increased citations - maximum visibility for your research: over $100 \mathrm{M}$ website views per year 